\title{
Leiomyosarcoma and Endometrial Stromal Sarcoma pT3b TNM Finding v7
}

National Cancer Institute

\section{Source}

National Cancer Institute. Leiomyosarcoma and Endometrial Stromal Sarcoma pT3b

TNM Finding v7. NCI Thesaurus. Code C89594.

Tumor infiltrates abdominal tissues, more than one site. (from AJCC 7th Ed.) 